\title{
PENGARUH REMITAN, JIWA ENTREPRENEURSHIP, KEMAPANAN BEKERJA PASCA MENJADI TKI, TERHADAP TINGKAT KESEJAHTERAAN TKI PURNA
}

\author{
Basrowi \\ Sekolah Tinggi Ekonomi dan Bisnis Islam (STEBI) Lampung \\ basrowi2018@gmail.com
}

\begin{abstract}
Abstrak: Tujuan penelitian ini adalah untuk mendeskripsikan pengaruh remitan, jiwa entrepreneurship, dan kemapanan bekerja pasca menjadi TKI baik secara parsial maupun simultan terhadap tingkat kesejahteraan Tenaga Kerja Indonesia (TKI) purna. Pendekatan yang digunakan dalam penelitian ini yaitu penelitian kuantitatif. Metode pengambilan data secara survei. Sampel penelitian berjumlah 240 orang TKI purna. Data yang telah terkumpul dianalisis dengan analisis univariate, bivariate, dan multivariate. Hasil analisis menunjukkan bahwa: ada pengaruh yang positif dan signifikan antara jumlah remitan, jiwa kewirausahaan, dan kemapanan bekerja baik secara parsial maupun simultan terhadap tingkat kesejahteraan TKI purna.
\end{abstract}

Kata kunci: TKI, Migram, Remitan, Keluarga, Masyarakat

\section{THE EFFECT OF REMITTION, ENTREPRENEURSHIP SOULS, POSSIBILITIES TO WORK POST TO BE TKI, TO THE WELFARE LEVEL OF THE TKI}

\begin{abstract}
The purpose of this study was to describe the effects of remittance, entrepreneurial spirit, and work stability after becoming migrant workers both partially and simultaneously to the level of welfare of Indonesian Workers (TKI) have returned. The approach used in this study is quantitative research. The process of collecting data uses the survey method. The research sample amounted to 240 TKI who have returned. Data that has been collected is analyzed with univariate, bivariate, and multivariate analysis. The results of the analysis show that: 1) there is a positive and significant influence between the number of remittances, entrepreneurial spirit, and establishment working both partially and simultaneously on the welfare level of TKI who have returned.
\end{abstract}

Keywords: Migrant Workers, Migrants, Remittances, Families, Communities

\section{PENDAHULUAN}

Komposisi pasar tenaga kerja di Indonesia saat ini menurut Iskandar (2012), "Ditandai dengan banyaknya jumlah tenaga kerja terdidik yang menganggur, yang disebabkan oleh rendahnya kompetensi, dan terbatasnya lapangan pekerjaan, serta lemahnya jiwa entrepreneurship mereka. Pengangguran terbuka juga mempunyai karakteristik berumur kurang dari 24 tahun." Saat ini, "Kelompok pengangguran terbuka juga diisi oleh mereka yang berpendidikan sekolah menengah pertama, sebagian besar berada di perkotaan sebanyak 5,8 juta jiwa, atau sebanyak $52,4 \%$. Hanya saja, pada kurun waktu 5 (lima) tahun terakhir, keberadaan pengangguran juga merambah daerah perdesaan. Selain masalah pengangguran terbuka yang jumlahnya semakin bertambah, jumlah para pekerja yang bekerja di bawah 35 jam/minggu, jumlahnya juga selalu meningkat (dari 29,8\% bertambah menjadi 31,4\% )" (Iskandar, 2012).

Matteucci (2007) mengatakan bahwa, "Sedikitnya ada empat alasan yang mendorong seseorang bermigrasi mencari pekerjaan secara internasional, yaitu karena: 1) alasan wealth atau kemakmuran, 2) alasan weather atau cuaca yang ada di negaranya tidak sesuai dengan kesehatan dirinya, 3) alasan water atau air yang ada di negaranya tidak sehat untuk dirinya, dan 4) alasan warfare atau keamanan akibat perang atau konflik berkepanjangan yang tidak berkesudahan." 
Asalan pertama, karena terdorong untuk mencari kemakmuran atau kesejahteraan (wealth) merupakan salah satu alasan paling populer bagi tenaga kerja Indonesia yang melakukan migrasi ke negara lain, yang mempunyai likuiditas untuk melakukan pembayaran gaji mereka yang lebih besar dibandingkan dengan kemampuan bayar berbagai perusahaan di negaranya. Hal itulah yang menjadi reasoning pertama, seseorang melakukan migrasi ke negara tetangga, dan negara lain seperti ke benua Eropa, Amerika, Asia, dan lainnya. Semua itu, mereka lakukan demi mendapatkan kesejahteraan yang lebih baik, baik saat mereka bekerja maupun pada saat mereka telah purna.

Para calo dan PJTKI, "Mereka membuat gambaran kesejahteraan yang sangat menggiurkan para TKI dan membuat iming-iming yang mampu menghipnotis pada calon TKI, sehingga mereka mau mengikuti keinginan mereka untuk bekerja di negara lain dengan gaji yang tinggi. Umumnya mereka mengarah pada para calon KTI yang mempunyai keterampilan rendah, informasi ketenagakerjaan rendah, dan mereka mau menjadi pembantu rumah tangga." (Siagian, 2006 ).

Banyak TKI, "Dengan alasan bosan terlilit kemiskinan di kampung sendiri, diiringi terbatasnya lahan yang bisa digarap, maka mereka memutuskan untuk menjadi TKI/TKW. Bekerja di luar negeri tentu lebih menjanjikan dari segi ekonomi. Segi sosialpun terangkat. TKI/TKW itu dipandang lebih bergengsi daripada cuma jadi buruh pabrik, apalagi sekadar menjadi pembantu rumah tangga di negeri sendiri." (Tresnawati, 2014).

Selain itu, menurut Primawati, (2011) "Migran juga mempunyai keinginan untuk hidup lebih sejahtera. Hal ini erat kaitannya dengan fungsi investasi, mereka akan membangun rumah atau membeli tanah di daerah asal sebagai simbol kesejahteraan, prestisius dan kesuksesan di daerah rantau." Lee (dalam Primawati, 2011) mengemukakan bahwa, "Berbagai pengalaman baru yang diperoleh di tempat tujuan, apakah itu keterampilan khusus atau kekayaan, sering dapat menyebabkan orang kembali ke tempat asal dengan posisi yang lebih menguntungkan."

Berbagai penelitian terdahulu berkaitan dengan penelitian ini, antara lain penelitian Sander and Maimbo (2003) yang menyimpulkan bahwa, "Remitansi yang dikirimkan oleh tenaga migran ke negara asalnya di Afrika mampu memutar roda perekonomian di daerah asal dan mampu memajukan Negara asal." Mafruhah, Sarsito, and Gravitiani (2013) menemukan bahwa, "Remitansi TKI digunanan untuk (1) consumption, (2) personal saving in gold and bank, (3) personal or collective investment. Semakin besar remitansi digunakan untuk menabung di bank dan emas atau investsi semakin besar tingkat kesejahteraan TKI purna." Effendi (1993 dalam Primawati, 2011) dalam penelitiannya di tiga desa di Jatinom, Klaten menemukan bahwa remitansi telah digunakan untuk modal usaha pada usaha-usaha skala kecil seperti pertanian jeruk, peternakan ayam, perdagagan dan bengkel sepeda." Penelitian Hugo (2005), "Terdapat dampak yang signifikan dari migrasi perempuan ke negara-negara Timur Tengah dan ke luar negeri terhadap peningkatan kesejahteraan keluarga." Setiadi (2001) menyimpulkan bahwa, "Berbagai macam pengalaman yang diperoleh berupa keterampilan dan pengalaman kerja migran dapat diaplikasikan untuk membuka usaha di daerah asal sehingga mampu meningkatkan tingkat kesejahteraan ekonomi migran."

Mahmood, Raisul Awal (dalam Setiadi, 2001) menyimpulkan bahwa, "Pekerja migran mempunyai dampak yang sangat besar bagi perubahan sosial ekonomi rumah tangga migran." Thielemann's (2008) mengkonfirmasi hasil penelitian para ahli sebelumnya bahwa, "Kesejahteraan mempunyai magnet effects yang luar biasa bagi tenaga kerja migran ke luar negeri." Seseorang mau bekerja di luar negeri menurut Thielemann (2008) karena, "Adanya bayangan akan memperoleh kesejahteraan baik saat bekerja maupun setelah pulang dari bekerja di luar negeri."

Menz (2008) berargumentasi bahwa, "Negara maju dengan tingkat upah yang tinggi, yang mampu meningkatkan tingkat kesejahteraan para migran dan para keluarganya." Pedersen, Pytlikova, dan Smith (2008); Pedersen, Pytlikova, dan Smith. (2008) juga menjelaskan bahwa, 
"Semakin banyak tenaga kerja migran yang bekerja di Negara maju semakin besar pula sumbangan tenaga kerja migran tersebut dalam meningkatkan rata-rata tingkat kesejahteraan rakyat di negaranya."

Melihat besarnya pengaruh remitan, bagi kesejahteraan TKI, maka penelitian ini bermaksud membuktikan besarnya pengaruh remitan dan variabel lain terhadap tingkat kesejahteraan TKI setelah mereka pulang ke kampung halamannya. Ketika remitan memberikan pengaruh bagi kesejahteraan keluarga TKI, maka diharapkan para TKI dapat mengirimkan remitan sebanyakbanyaknya sehingga dapat dijadikan modal usaha bagi keluarga dan bagi TKI itu sendiri di kemudian hari pada saat mereka telah kembali.

Sesuai dengan migration theory yang dikembangkan oleh Lee and Keban (dalam Mafruhah, Sarsito, and Gravitiani, 2013) mengatakan bahwa: "People migrate because of the need and the stress. Theory of stress-threshold or place utility model says that stress will occur to people who are unable to fulfill their greater need. People will move away or migrate if their stress is in the threshold, and they fail to fulfil their hope or need. Unemployment and poverty, inadequate infrastructure, a complicated regulatory environment, and regional inequality are all push factors driving international migration."

Pendapat di atas senada dengan teori ekonomi makro klasik yang mengatakan bahwa, "Workers move from surplus labor countries and poor countries to countries that lack labor and rich countries, while capital flows in the opposite direction." (Massey et al, dalam Mafruhah dan Mulyani, 2014). Giorgi and Pellizzari (2008) menyimpulkan bahwa, "Dengan penghasilan yang tinggi para pekerja merasa lebih sejahtera dibandingkan sebelum menjadi tenaga kerja migran." Baum (2012) menyatakan bahwa, "Migran dengan tingkat pendidikan yang tinggi, kualitas pendidikan dan latihan yang diberikan, dan komitmen untuk menjadi tenaga migran mempunyai pengaruh yang besar terhadap penghasilan dan lama tidaknya menjadi migran."

Gibson and McKenzie (2011) menyimpulkan bahwa, "Terjadi tidaknya buruh migran sangat tergantung pada tingkat sosial ekonomi masyarakat. Tenaga migran terjadi karena di Negara asal masih dalam kondisi yang miskin, kesempatan bekerja renda, dan dengan menjadi migran diharapkan dapat terbuka kesempatan memperoleh pekerjaan yang layak, dan terbebas dari kemiskinan." "Tingkat kesejahteraan dapat direfleksikan melalui jumlah investasi yang telah ditanam oleh TKI baik dalam bentuk tabungan uang (deposito), tanah/sawah, ternak sapi/kerbau, emas, rumah, atau kendaraan." (Soepomo, 2003: 76).

Piracha dan Vadean (2012); Mafruhah, Sarsito, and Gravitiani, (2013) menjelaskan bahwa, "The main reason of TKI to go abroad is to find a better job for higher income. Beside that, the success story of their friends makes them willing to go abroad for work. BNP2TKI announces TKI is a safeguard. After they return home, they could become entrepreuners. But, it would depend on how they use their remittances in their origin area in Indonesia. Th success of TKI in their future life would depend on the placement, life pattern, and the environment around where they live." Andrew dan Withey, Campbell, Catrill (dalam Leung \& Leung, 2012), "Kesejahteraan hidup yang bersifat lahir sangat berkaitan dengan tingkat pendapatan dan jumlah aset yang dimiliki." Menurut Cole dan Hall (dalam Ali, 2003), "Kesejahteraan hidup adalah satu keadaan emosi yang dapat mempengaruhi corak hidup individu. Individu yang menjalani hidup dengan tenang, puas, gembira, dan jarang memperlihatkan akhlak yang kurang baik, maka ia disebut sejahtera." Konsep kesejahteraan yang dikemukakan Cole dan Hall (dalam Ali, 2003) inilah yang selanjutnya disebut dengan kesejahteraan batin. Sementara itu, konsep kesejahteraan yang dibahas Andrew dan Withey, Campbell, Catrill (dalam Leung \& Leung, 2012) merupakan kesejahteraan yang bersifat lahir.

Teori yang digunakan dalam penelitian ini yaitu teori kesejahteraan dari Westfall (2012); Sudarma (2011); "Konstruk kesejahteraan diukur dengan dimensi: 1) kesejahteraan lahir dan 2) 
kesejahteraan batin. Dimensi kesejahteraan lahir mempunyai indikator: a) upah, b) kualitas tempat tinggal, c) kualitas perabotan rumah, d) kualitas sarana hiburan, d) sarana transportasi, dan e) kepemilikan aset. Dimensi kesejahteraan batin mempunyai indikator: a) penerimaan diri, b) hubungan yang positif dengan orang lain, dan c) pertumbuhan pribadi."

Hasil survey Bank Indonesia (2008) menyimpulkan bahwa, "Motivasi TKI pada umumnya seragam yakni mencari penghasilan yang lebih baik. Dengan penghasilan yang lebih baik, kehidupan keluarga mereka menjadi lebih baik, dapat hidup lebih terpandang dan sejahtera serta menyekolahkan anak." Selanjutnya, Yulinda (2012) mengungkapkan bahwa, "Faktor-faktor yang menjadi daya dorong menjadi TKI masyarakat desa Mundakjaya Kecamatan Cikedung Kabupaten Indramayu, Jawa Barat, yaitu sempitnya lapangan pekerjaan dan kurangnya sumber daya alam. Sedangkan faktor-faktor yang menjadi daya tarik, yaitu karena adanya contoh TKI yang tingkat kesejahteraannya meningkat, kesempatan kerja, upah kerja di luar negeri, informasi di daerah tujuan, adanya ajakan pihak lain, dan persyaratan yang mudah untuk menjadi TKI."

Hani (2012) mengungkapkan bahwa, "Motivasi penduduk yang menjadi TKI karena 1) lahan pertanian semakin sempit, kesempatan kerja yang bersifat musiman, dan upah yang rendah,; 2) aspek yang mendorong adalah agar pendapatan usaha meningkat." King, et.al (1998), dalam melakukan penelitian terhadap 1066 tenaga kerja migran di Eropa menyimpulkan bahwa, "Remitan sangat bermanfaat bagi pengembangan geografi ekonomi di daerah asal." Utamaningsih \& Siagian, (2006) menjelaskan bahwa, "Kesejahteraan tenaga kerja sangat dipengaruhi oleh tingkat penghasilan dan pendapatan lain yang diperoleh selama bekerja." Nagla (2011) menyimpulkan bahwa "Menjadi migran diharapkan akan mampu meningkatkan tingkat kesejahteraan yang selama ini diidam-idamkan. Harapan akan kesejahteraan, ketiadaan ketergantungan dengan orang lain, telah menyebabkan terjadinya migrasi internasional."

Sudarma, (2011) menjelaskan bahwa, "Prosperity becoming an ideality for every employee because welfare is a state where persons feel any peace and prosperity. This means that welfare is closely linked with the quality of life (quality of work life). If the prosperity of civil servants is low, then increase the quality of life will be difficult to realize." Jadi, secara teoretik kesejahteraan dipengaruhi oleh besar-kecilnya remiten, jiwa entrepreneurship, dan kemapanan pekerjaan setelah pulang ke kampung halaman.

Rahman, (2012) dalam melakukan penelitian terhadap pekerja Migran asli Banglades di Singapura menyimpulkan, "Penghasilan sebagai pekerja migran akan mampu meningkatkan motivasi mereka dalam usaha meningkatkan status. Remitan yang mereka kirim ke Banglades sebagai modal untuk mewujudkan bentuk ekonomi baru. Hal ini menunjukkan bahwa keputusan menjadi migran merupakan pilihan rasional yang tepat."

Jiwa entrepreneurship merupakan, "Gambaran perasaan senang yang dimiliki oleh seseorang terhadap satu atau beberapa jenis usaha yang diyakini akan mampu memberikan keuntungan material. Jiwa entrepreneurship juga dapat dipahami sebagai sebuah keyakinan yang melekat pada diri seseorang terhadap kegiatan bisnis yang benar-benar akan mampu memberikan keuntungan. Jiwa entrepreneurship juga dapat disebut sebagai sebuah cara pandang seseorang terhadap usaha bisnis yang diyakininya akan mampu memberikan manfaat ekonomi yang besar bagi diri dan keluarganya. Sikap mental ini dipengaruhi oleh persepsi terhadap bisnis, kemampuan melakukan bisnis, harapan akan keberhasilan, cita-cita, lingkungan keluarga dan masyarakat, modal yang dimiliki, dan dukungan keluarga." (Busro, 2017).

Adapun kemapanan kerja pasca menjadi TKI, merupakan suatu keadaan dan aktivitas yang dilakukan oleh para mantan TKI setelah mereka tinggal di daerah asal dengan berbagai bentuk aktivitas ekonomi produktif yang kreatif, seperti penyewaan sound system, tenda dan kursi untuk 
berbagai keperluan, papan bunga, laundry, menggarap sawah dan kebon, rental mobil, pom bensin mini, dan lain-lain.

Permasalahan saat ini yang dihadapi tenaga kerja Indonesia (TKI) di luar negeri berkaitan dengan uang kiriman ke daerah asal (remitan) adalah banyaknya remitan yang disalahgunakan oleh keluarga yang di kampung halaman, seperti digunakan untuk konsumtif, hidup boros, berfoya-foya, bahkan disalahgunakan oleh keluarga terdekatnya. Banyak remitan yang digunakan untuk membeli berbagai barang elektronik, kendaraan bermotor, alat komunikasi, dan berbagai alat rumah tangga yang tidak bisa dijual lagi, atau seandainya dijual sudah tidak mempunyai nilai ekonomi lagi. Sedikit sekali jumlah remitan yang digunakan untuk investasi seperti membeli hewan ternak, emas, tabungan di bank, sawah, maupun untuk membeli tanah produktif yang dapat dijual dengan harga yang tinggi.

\section{METODE}

Membaca latar belakang, rumusan masalah, dan tujuan penelitian sebagaimana dijelaskan di atas, metode yang paling tepat untuk menjawab rumusan masalah adalah survey deskriptif, dan survey yang bersifat eksplanatory. Penelitian ini mengambil lokasi di Kabupaten Purworejo dan Kabupaten Kebumen, Jawa Tengah. Data yang bersifat langsung dari responden atau disebut dengan data primer diperoleh melalui penyebaran instrumen, yang kemudian dianalisis uji asumsinya. Berdasarkan hasil analisis seluruh uji asumsi klasik terpenuhi, kemudian dilanjutkan dengan uji hipotesis.

Pada penelitian ini populasi adalah seluruh eks TKI dari Malaysia dan Arab Saudi dan telah kembali ke Indonesia. Jumlah populasi adalah 648 TKI yang tersebar di 32 Kecamatan. Sampel berjumlah 240 orang TKI Purna. Data dianalisis secara parsial dan simultan dengan tiga tahapan analisis yaitu analisis univariate, bivariate, dan multivariate.

\section{HASIL DAN PEMBAHASAN}

Hasil analisis uji statistik pengaruh X1 terhadap Y, X2 terhadap Y, dan X3 terhadap Y, serta X1,2,3 terhadap Y dapat ditabulasikan sebagai berikut.

Tabel 1. Hasil Analisis Data

\begin{tabular}{clcllrc}
\hline Uji Pengaruh & \multicolumn{1}{c}{ t } & Sign & \multicolumn{1}{c}{ F } & \multicolumn{1}{c}{ Sign } & $\mathbf{R}^{2}$ & R adj \\
\hline X1-Y & 10,386 & 0,000 & 107,869 & 0,00 & 0,312 & 0,309 \\
X2-Y & 14,229 & 0,000 & 202,474 & 0,000 & 0,460 & 0,457 \\
X3-Y & 9,847 & 0,000 & 96,966 & 0,000 & 0,289 & 0,286 \\
X1,2,3 Y & 20.290 & 0,000 & 138,291 & 0,000 & 0,637 & 0,633 \\
\hline
\end{tabular}

Hipotesis statistik ke-1 yaitu $\mathrm{H}_{0}: \gamma_{1}=0$ : Tidak ada pengaruh banyaknya remitan terhadap kesejahteraan TKI purna; $\mathrm{H}_{1}: \gamma_{1} \neq 0$ : Jumlah remitan berpengaruh signifikan terhadap kesejahteraan TKI purna. Berdasarkan hasil perhitungan diperoleh koefisien jalur banyaknya remitan terhadap kesejahteraan menunjukkan nilai t hitung sebesar 10,386. Nilai tersebut sudah memenuhi syarat untuk penerimaan $\mathrm{H} 1$ untuk hipotesis ke-1 yaitu nilai $t$ hitung yang lebih besar dari tabel sebesar 1,96. Dengan demikian dapat disimpulkan, dimensi-dimensi banyaknya remitan terbukti berpengaruh signifikan terhadap kesejahteraan TKI. Dapat dinyatakan bahwa semakin banyak jumlah remitan TKI maka akan semakin tinggi pula tingkat kesejahteraan TKI tersebut, dan sebaliknya, semakin rendah jumlah remitan maka akan berimplikasi pada rendahnya kesejahteraan TKI. Dengan kata lain, remiten yang dikirimkan oleh TKI ke kampung halamannya, akan mampu 
meningkatkan kesejahteraan anggota keluarga mereka yang tinggal di kampung halaman, dan mampu menambah aset mereka yang dapat dimanfaatkan di kemudian hari, setelah mereka purna.

Implikasi temuan ini menunjukkan bahwa kebutuhan untuk meningkatkan kesejahteraan TKI dapat dilakukan dengan meningkatkan jumlah remitan yang dikirim dan ditabung oleh keluaga mereka. Dengan demikian, kebutuhan untuk meningkatkan kesejahteraan TKI terkait dengan peningkatan jumlah remitan yang dikirimkan, ditabungkan, dan belikan barang produktif. TKI dapat diarahkan untuk selalu mengirimkan remitannya ke tanah air sehingga mampu menghasilkan modal kerja produktif yang tinggi

Hipotesis Statistik ke-2, yaitu $\mathrm{H}_{0}: \gamma_{2}=0$ : Tidak ada pengaruh jiwa entrepreneurship terhadap kesejahteraan TKI purna; $\mathrm{H}_{1}: \gamma_{2} \neq 0$ : jiwa entrepreneurship berpengaruh signifikan terhadap kesejahteraan TKI purna. Berdasarkan hasil perhitungan diperoleh koefisien jalur jiwa entrepreneurship terhadap kesejahteraan TKI Purna menunjukkan nilai koefisien t hitung sebesar 14,229. Nilai tersebut sudah memenuhi syarat untuk penerimaan H1 untuk hipotesisi ke-2 yaitu nilai t hitung yang lebih besar dari 1,96. Dengan demikian dapat disimpulkan, dimensi-dimensi jiwa entrepreneurship terbukti berpengaruh signifikan terhadap kesejahteraan TKI purna. Implikasi temuan ini yaitu bahwa di dalam meningkatkan kesejahteraan TKI, maka TKI harus memiliki jiwa entrepreneurship yang tinggi. Ketika TKI mempunyai jiwa entrepreneurship yang tinggi, maka setelah ia pulang dari luar negeri maka akan langsung melakukan berbagai usaha bisnis, sehingga ia tidak menganggur. Dengan melakukan berbagai usaha bisnis yang produktif, maka tingkat kesejahteraan TKI Purna akan meningkat, seiring dengan kemajuan usaha bisnis yang dijalankannya.

Hipotesis Statistik ke-3, yaitu $\mathrm{H}_{0}: \gamma 3=0$ : Tidak ada pengaruh antara kemapanan kerja pasca menjadi TKI terhadap kesejahteraan TKI purna; $\mathrm{H}_{1}: \gamma_{3} \neq 0$ : tingkat kemapanan bekerja pasca menjadi TKI berpengaruh signifikan terhadap kesejahteraan TKI purna. Berdasarkan hasil perhitungan diperoleh koefisien jalur tingkat kemapanan bekerja pasca menjadi TKI terhadap kesejahteraan TKI Purna menunjukkan nilai koefisien thitung sebesar 9,847. Nilai tersebut sudah memenuhi syarat untuk penerimaan $\mathrm{H} 1$ untuk hipotesis ke-3 yaitu nilai t hitung yang lebih besar dari 1,96. Dengan demikian dapat disimpulkan, dimensi-dimensi tingkat kemapanan bekerja pasca menjadi TKI terbukti berpengaruh signifikan terhadap kesejahteraan TKI purna.

Implikasi temuan ini yaitu bahwa di dalam meningkatkan kesejahteraan TKI, maka TKI harus memiliki tingkat kemapanan bekerja pasca menjadi TKI yang tinggi. Ketika TKI mempunyai tingkat kemapanan bekerja pasca menjadi TKI yang tinggi, maka setelah ia pulang dari luar negeri maka akan langsung memilih pekerjaan yang mapan, sehingga ia tidak menganggur. Dengan melakukan pekerjaan yang mapan, maka tingkat kesejahteraan TKI Purna akan meningkat, seiring dengan tingkat kemapanan bekerja pasca menjadi TKI. Hasil penelitian ini juga berimplikasi bahwa untuk meningkatkan kesejahteraan TKI, maka eks TKI harus mampu melakukan pekerjaan di tempat asalnya dengan jenis pekerjaan yang mapan, bukan sambilan. Dengan berbagai keterampilan yang telah diperoleh di luar negeri diharapkan mampu mengaplikasikan pada saat setelah pulang ke kampung halamannya. Dengan demikian, tingkat kemapanan pekerjaan pasca menjadi TKI bersifat sangat tinggi. Dengan kata lain, ketika eks TKI mempunyai tingkat kemapanan pekerjaan yang tinggi pasca menjadi TKI maka tingkat kesejahteraan mereka akan meningkat, karena dengan pekerjaan yang mapan tersebut akan mampu menghasilkan pendapatan yang relatif tinggi, dibandingkan pada saat sebelum berangkat ke luar negeri.

Persamaan yang diperoleh dari uji hipotesis keempat, diperoleh model kinerja melalui nilai standard estimate adalah sebagai berikut: KSJ $=0.354^{*}$ Kemap $+0.343^{*}$ Entre $+0.313^{*}$ Remit. $\mathrm{R}^{2}=$ 0.637. Angka $R$ square mengandung makna variasi kesejahteraan mampu dijelaskan oleh remiten, 
jiwa entrepreneurship, dan kemapanan bekerja pasca menjadi TKI sebesar $63,7 \%$, dan sisanya $36,3 \%$ dipengaruhi variabel lain yang tidak diteliti dalam model.

Karena estimasi pada model struktural ini menggunakan pendekatan regresi, maka evaluasi atas signifikansi model dihitung menggunakan uji $\mathrm{F}$, di mana, $\mathrm{R}^{2}$ adalah koefisien determinasi, $\mathrm{n}$ adalah jumlah observasi, $\mathrm{m}$ adalah jumlah variabel bebas. Melalui perhitungan diperoleh nilai $\mathrm{F}$ hitung sebesar 138,291 Sedangkan nilai $\mathrm{F}$ tabel dengan jumlah variabel bebas 3 , dan $\mathrm{df}=\mathrm{n}-\mathrm{k}-1$ yaitu $n$ adalah jumlah sampel, $\mathrm{k}$ adalah jumlah variabel bebas sehingga $\mathrm{df}=240-3-1=236$, sehingga diperoleh nilai $\mathrm{F}$ tabel 2.64. Karena nilai $\mathrm{F}$ hitung $>\mathrm{F}$ tabel $(342.55>2.64)$, maka model simultan ini diterima.

Dengan demikian dapat dipahami bahwa remiten, jiwa entrepreneurship, dan Kemapanan Bekerja Pasca Menjadi TKI mempunyai pengaruh signifikan secara bersama-sama terhadap tingkat kesejahteraan TKI Purna. Ketika TKI selama bekerja di luar negeri secara rutin mengirimkan remitannya, dan ia mempunyai jiwa entrepreneurship yang tinggi, serta mampu menciptakan lapangan pekerjaan bagi diri sendiri setelah pulang ke kampung halamannya, maka ia akan semakin sejahtera baik dibandingkan pada saat sebelum berangkat ke luar negeri maupun pada saat berada di luar negeri.

Berdasarkan hasil penelitian di atas dapat dipahami bahwa kesejahteraan menjadi idaman bagi setiap orang (termasuk TKI) karena kesejahteraan merupakan keadaan di mana seseorang merasakan adanya ketenteraman dan kemakmuran. Ini berarti kesejahteraan sangat berkaitan dengan kualitas kehidupan (quality of work life). Jika kesejahteraan (TKI) masih rendah, maka peningkatan kualitas kehidupan akan sulit untuk direalisasikan.

Hasil penelitian ini sesuai dengan temuan Primawati (2011) yang menyimpulkan bahwa satu bentuk aktivitas yang dilakukan TKI berdasarkan keputusan-keputusan dan pertimbanganpertimbangan rasional adalah bahwa mereka mau menjadi TKI karena untuk mendapatkan tingkat kehidupan ekonomi dan sosial yang lebih baik dan lebih layak bukan untuk tetap menetap dan melakukan aktivitas ekonomi di daerah asal.

Hasil penelitian ini juga sesuai dengan temuan Primawati (2011) yang menyimpulkan bahwa untuk mendapatkan kesejahteraan pasca menjadi TKI, maka para TKI akan melakukan investasi. Tindakan ini dilakukan dalam bentuk perbaikan dan pembangunan perumahan, membeli tanah, mendirikan industri kecil dan lain-lainnya. Kegiatan ini tidak hanya bersifat ekonomi, tetapi juga bersifat psikologis sebagai sarana sosial dan budaya dalam menjaga kelangsungan hidup di daerah asal, karena erat hubungannya dengan prestise seseorang.

Begitu juga penelitian Prasetia (2011) yang melakukan penelitian tentang "Pengiriman Tenaga Kerja Indonesia (TKI) ke Malaysia Melalui Kota Semarang" menyimpulkan bahwa, "Makna dari pengiriman TKI asal Kota Semarang ke Malaysia seperti adanya peningkatan kesejahteraan, tidak hanya TKI yang pergi tetapi juga keluarga dan kampung yang ditinggalkan. Selain itu, pengiriman TKI juga bermakna pada peningkatan devisa negara. Para TKI yang dikirim tidak hanya memperoleh keuntungan berupa uang, tetapi juga keuntungan dalam hal peningkatan keterampilan kerja. Pengiriman TKI juga akan bermakna pada pengurangan masalah pengangguran di dalam negeri. Dengan pelatihan yang mantap maka kepercayaan diri TKI aka semakin meningkat yang selanjutnya akan meningkatkan kesejahteraan TKI."

Hasil penelitian Wiresapta (2008) yang meneliti tentang, "Migrasi Internasional Tenaga Kerja Indonesia (TKI) ke Malaysia: Proses dan Dampak Sosial Budaya di Daerah Asal (Studi Kasus di Pedesaaan Pulau Lombok, Nusa Tenggara Barat)." Ia juga menyimpulkan bahwa, "Migran (TKI) asal pulau Lombok sangat kurang apresiasinya terhadap upaya peningkatan kapabilitas diri sebelum pemberangkatan, namun, kinerja TKI asal pulau Lombok di negara tujuan (Malaysia) relatif baik. 
Keputusan untuk bermigrasi pada dasarnya adalah keputusan keluarga karena terkait harapan untuk memperbaiki taraf hidup (kesejahteraan) keluarga."

Hasil penelitian ini mendukung temuan Vithessonthi \& Schwaninger, M. (2008) menyatakan bahwa, "That employees with high levels of self-confidence for learning and development tend to feel more comfortable with organizational change than those with low levels of self-confidence for learning and development. Because employees' self-confidence for learning and development is likely to influence the degree to which employees actually learn and develop, low levels of self-confidence for learning and development may cause employees to be afraid of potential failures to perform in a new work environment, because of their limited capability to learn new."

Hasil penelitian ini sesuai dengan temuan Rahman, (2012) dalam melakukan penelitian terhadap pekerja Migran asli Bangladesh di Singapura menyimpulkan bahwa, "Motivasi bekerja para Pekerja migran kontrak dari Bangladesh di Singapura sangat tinggi. Tingginya motivasi disebabkan oleh tingginya gaji yang diterima oleh pekerja migran di Singapore. Singapore merupakan madu bagi pekerja kelas bawah. Singapore merupakan salah satu pilihan favorit destinasi pekerja migran, karena terkenal memberikan rate gaji yang sangat tinggi. Rata-rata gaji pekerja rendahan di sana mencapai $\$ \$ 712$ per bulan (setara dengan Rp6.640.000,00), dengan ratarata jumlah tabungan sebesar $\mathrm{S} \$ 433$ per bulan. Mereka sangat bahagia dan termotivasi dengan gaji mereka. Hal ini merupakan strategi untuk meningkatkan status sosial ekonomi mereka. Penghasilan sebagai pekerja migran akan mampu meningkatkan motivasi mereka dalam usaha meningkatkan status".

Hasil penelitian ini pada dasarnya juga mengokohkan temuan Prasetia (2011) mencatat, bahwa, "Alasan imigran paling utama meninggalkan Indonesia adalah karena faktor ekonomi, serta wujudnya keinginan untuk mendapatkan penghasilan yang lebih tinggi. Sebagian kecil saja, karena alasan mengikuti keluarga."

Catatan tersebut sejalan dengan hasil kajian Pongsapich (2009: 17) tentang orang Asia yang bekerja di Timur Tengah, bahwa, "Banyak penduduk negara berkembang bekerja di negara maju karena mereka kurang atau tidak memperoleh peluang ekonomi yang layak di negara asalnya. Beberapa alasan TKI asal Indonesia karena adanya beberapa dorongan, seperti dorongan ekonomi, dorongan Keluarga, dan dorongan cerita yang berkembang."

\section{SIMPULAN}

Berdasarkan hasil analisis data dapat disimpulkan bahwa:

1. Terdapat pengaruh yang signifikan antara jumlah remitan yang dikirimkan terhadap tingkat kesejahteraan TKI purna, semakin tinggi tingkat remitan yang dikirim ke keluarganya semakin tinggi pula tingkat kesejahteraan TKI purna dan sebaliknya;

2. Terdapat pengaruh yang signifikan antara jiwa entrepreneurship terhadap tingkat kesejahteraan TKI, semakin tinggi jiwa entrepreneurshipnya, semakin tinggi pula tingkat kesejahteraan TKI dan sebaliknya;

3. Terdapat pengaruh yang signifikan antara tingkat kemapanan bekerja pasca menjadi TKI terhadap tingkat kesejahteraan TKI, semakin tinggi tingkat kemapanan pekerjaan yang dilakukan TKI pasca menjadi TKI semakin tinggi pula tingkat kesejahteraan TKI dan sebaliknya;

4. Terdapat pengaruh yang signifikan secara bersama-sama antara remiten, jiwa entrepreneurship, dan kemapanan bekerja pasca menjadi TKI terhadap tingkat kesejahteraan TKI, semakin tinggi tingkat remiten, jiwa entrepreneurship, dan kemapanan bekerja pasca menjadi TKI semakin tinggi pula tingkat kesejahteraan TKI dan sebaliknya. 


\section{DAFTAR PUSTAKA}

Ali, Alizarinah. (2003). Konsep Kendiri Remaja Lelaki yang Ponteng Sekolah. Satu Kajian Kes Di Sekolah Dato' Jaafar, Johor Bahru. Fakulti Pendidikan, Universiti Teknologi Malaysia. Latihan Ilmiah yang Tidak Diterbitkan

Bank Indonesia. (2008). Hasil Survei Nasional Pola Remitansi TKI di Nusa Tenggara Barat tahun 2008, Jakarta: BI

Baum, Tom. (2012). Migrant Workers in the International Hotel Industry, The International Labour Office Enjoy Copyright under Protocol 2 of the Universal Copyright Convention, International Labour Office, CH-1211 Geneva 22, Switzerland

Busro, M. (2017). Studi Kelayakan Usaha, Yogyakarta: Graha Ilmu

Gibson, J. and D. McKenzie. (2011). 'How Can Developing Countries Governments Facilitate International Migration for Poverty Reduction?', in: Murrugarra, E., Larrison, J. and M. Sasin (eds.) Migration and Poverty. Toward Better Opportunities for the Poor, The World Bank, Washington, D.C., $125-143$.

Giorgi De, G. dan Pellizzari, M. (2008). Welfare Migration in Europe. Labour Economics, Vol. 16: $353-363$.

Hani, Evita Soliha. (2012). Implementasi Kebijakan Ekspor Jasa Tenaga Kerja Indonesia (TKI) di Jawa Timur. Disertasi, Malang: Program Pascasarjana (PPS) Universitas Brawijaya

Hugo, Graeme. (2005). National Programme for Indonesian Labour, Export Services, Repelita VI. Stage 1, Jakarta: Departmen of Labour

Iskandar, Muhaimin. (2012). TKI Tahun ini di Atas 100.000, diunduh tanggal 4 Oktober 2018 dari http://detik.com (15/8/2012)

King, Russell et.al. (2008). International Retirement Migration in Europe, International Journal of Population Geography, Volume 4, Issue 2, pages 91-111diunduh pada tanggal 22 Oktober 2018 dari http://www.jstor.org/stable/2938462.

Lee, Lena and Poh Kam Wong. (2006). "Individual Attitudes, Organizational Reward System And Patenting Performance Of R\&D Scientists And Engineers", Journal MPRA, Vol. 7, No. 595, p.1-44.

Leung, J. G. \& Leung, K. (2012). Life Satisfaction, Self-Concept, and Relationship With Parents in Adolescence. Journal of Youth and Adolescence. 21(6), 635-665.

Mafruhah, Izza; Totok Sarsito, and Evi Gravitiani. (2013). The Welfare of the Indonesian Migrant Workers (TKI) in the Land of a Malay Nation: A Socio-Economic Analysis, Southeast Asian Journal of Social and Political Issues, Vol. 1, No. 2, March 2013. pp 247-270

Matteucci, Annamariana \&. Bolletti, Marina. (2007). "Developing of a collaborative program for information skills teaching at Liceo "Cornaro" in Padua". Innovation in Education and Teaching International. Vol. 32-40, pg 1-14

Menz, G. (2008). "Useful" Gastarbeiter, burdensome asylum seekers, and the second wave of welfare retrenchment: Exploring the nexus between migration and the welfare state, p. 393 418 in: C. A. Parsons / T. M. Smeeding (eds.), Immigration and Transformation of Europe. Cambridge: University Press

Pedersen, P. J.; M. Pytlikova, dan N. Smith, (2008). Migration into OECD Countries 1990 - 2000, p. 43 - 84 in: C. A. Parsons / T. M. Smeeding (eds.), Immigration and Transformation of Europe. Cambridge: University Press

Piracha, M. dan Vadean, F. (2012). Migrant Educational Mismatch and the Labour Market, Discussion Paper No. 6414 March 2012 
Pongsapich, A. (2009). The Case of Asian Migrants to the Gulf Region. International Journal: International Migration, Vol.27 No. 2 pp 171-183.

Prasetia, Irwan. (2011). Pengiriman Tenaga Kerja Indonesia (TKI) ke Malaysia melalui Kota Semarang, Jurnal On-line, diunduh tanggal 15 Oktober 2012 dari http://www.jurnal.online.tki.astra.internasional.bengkulu

Primawati, Anggraeni. (2011). Remitan Sebagai Dampak Migrasi Pekerja ke Malaysia, Sosiokonsepsia, Vol. 16 No. 02, Tahun 2011

Rahman, Mizanur. (2012). Migration as Status-Enhancement: A Study of Bangladeshi Workers in Singapore, Singapore: National University of Singapore, Diunduh tanggal 19 Oktober 2012 dari http://www.gradnet.de/papers/ pomo2.papers/rahman00.htm

Sander, C. and Maimbo, S.M. (2003). Migrant Labor Remittances in Africa: Reducing Obstacles to Developmental Contributions, Washington D.C.: World Bank, Africa Region Working Paper Series No. 64 November 2003

Setiadi. (2001). Migran Kembali: Permasalahan Reintegrasi Sosial dan Ekonomi, Center for Population and Policy Studies, Yogyakarta: Gadjah Mada University

Soepomo. (2003). Hukum Perburuhan, Bandung: Djambatan

Sudarma, Ketut. (2011). Analisis Kesejahteraan Berbasis Kinerja Melalui Competency dan Organizational Citizenship Behavior (OCB) pada Tenaga Administrasi: Studi Kasus pada Universitas Negeri Semarang (UNNES), Dinamika Sosial Ekonomi Volume 7 Nomor 1 Edisi Mei 2011 pp. 35--46

Thielemann, E. (2008). The Effectiveness of Governments' Attempts to Control Unwanted Migration, p. 442 - 472 in: C. A. Parsons / T. M. Smeeding (eds.), Immigration and Transformation of Europe. Cambridge: University Press.

Tresnawati. (2014). Nasib Miris Pahlawan Devisa, Riau Post 28 Januari 2014

Vithessonthi, C., \& Schwaninger, M. (2008). 'Job Motivation and Self-Confidence for Learning and Development as Predictors of Support for Change', Journal of Organizational Transformation and Social Change 5: 2, pp. 141-157, diunduh tanggal 4 Oktober 2018 dari http://www.doi: 10.1386/ jots.5.2.141/1

Westfall, Joseph. (2012). The Welfare of the Community, Boston College: Markkula Center for Applied Ethics

Wiresapta, Lalu. (2008). Migrasi Internasional Tenaga Kerja Indonesia (TKI) ke Malaysia: Proses dan Dampak Sosial Budaya di Daerah Asal (Studi Kasus di Pedesaaan Pulau Lombok, Nusa Tenggara Barat), Disertasi, Malang: PPs. Universita Brawijaya diunduh tanggal 15 Oktober 2018 dari http://www. prasetya.ub.ac.id/berita/Lalu-Wiresapta-Kesejahteraan-Keluarga-TKILombok-ke-Malaysia- id.html

Yulinda. (2012). Faktor-faktor yang Menjadi Daya Dorong Menjadi Tenaga Kerja Indonesia (TKI) Masyarakat Desa Mundakjaya Kecamatan Cikedung Kabupaten Indramayu, Jawa Barat. Laporan Hasil Penelitian. Diunduh tanggal 23 Februari 2018 dari http:aarch.upi.edu/st.php?export=html 